\title{
Reference Artifacts for NDE
}

M. Bono, et. al.

February 11, 2003

U.S. Department of Energy

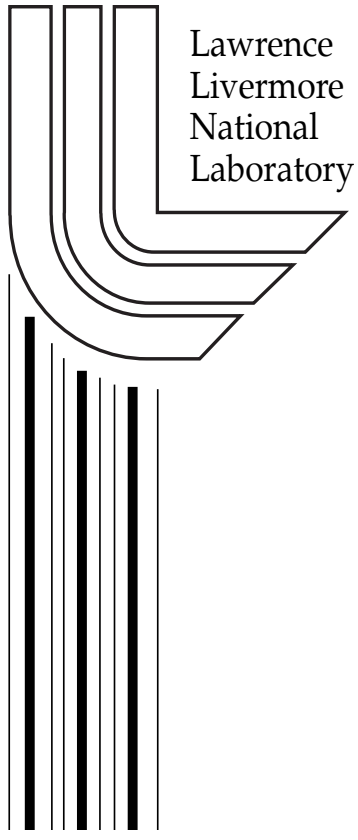




\section{DISCLAIMER}

This document was prepared as an account of work sponsored by an agency of the United States Government. Neither the United States Government nor the University of California nor any of their employees, makes any warranty, express or implied, or assumes any legal liability or responsibility for the accuracy, completeness, or usefulness of any information, apparatus, product, or process disclosed, or represents that its use would not infringe privately owned rights. Reference herein to any specific commercial product, process, or service by trade name, trademark, manufacturer, or otherwise, does not necessarily constitute or imply its endorsement, recommendation, or favoring by the United States Government or the University of California. The views and opinions of authors expressed herein do not necessarily state or reflect those of the United States Government or the University of California, and shall not be used for advertising or product endorsement purposes.

This work was performed under the auspices of the U. S. Department of Energy by the University of California, Lawrence Livermore National Laboratory under Contract No. W-7405-Eng-48.

This report has been reproduced directly from the best available copy.

Available electronically at http://www.doc.gov/bridge

Available for a processing fee to U.S. Department of Energy

And its contractors in paper from

U.S. Department of Energy

Office of Scientific and Technical Information

P.O. Box 62

Oak Ridge, TN 37831-0062

Telephone: (865) 576-8401

Facsimile: (865) 576-5728

E-mail: reports@adonis.osti.gov

Available for the sale to the public from

U.S. Department of Commerce

National Technical Information Service

5285 Port Royal Road

Springfield, VA 22161

Telephone: (800) 553-6847

Facsimile: (703) 605-6900

E-mail: orders@ntis.fedworld.gov

Online ordering: http://www.ntis.gov/ordering.htm

OR

Lawrence Livermore National Laboratory

Technical Information Department's Digital Library

http://www.llnl.gov/tid/Library.html 


\section{Reference Artifacts for NDE}

Revised 2/11/03

Two reference artifacts will be fabricated for this study. One of the artifacts will have a cylindrical geometry and will contain features similar to those on an SNRT target. The second artifact will have a spherical geometry and will contain features similar to those on a Double Shell target. The artifacts were designed for manufacturability and to provide a range of features that can be measured using NDE methods.

The cylindrical reference artifact is illustrated in Figure 1. This artifact consists of a polystyrene body containing two steps and a machined slot, into which will fit a tracer made of doped polystyrene. The polystyrene body contains several grooves and can be fabricated entirely on a diamond turning machine. The body can be machined by turning a PS rod to a diameter slightly greater than the finished diameter of $2 \mathrm{~mm}$. The part can be moved off-axis to face it off and to machine the steps, slot, and grooves. The tracer contains a drilled hole and a milled slot, which could be machined with a single setup on a milling machine. Once assembled, the artifact could be placed in a Be tube or other structure relevant to target assemblies.

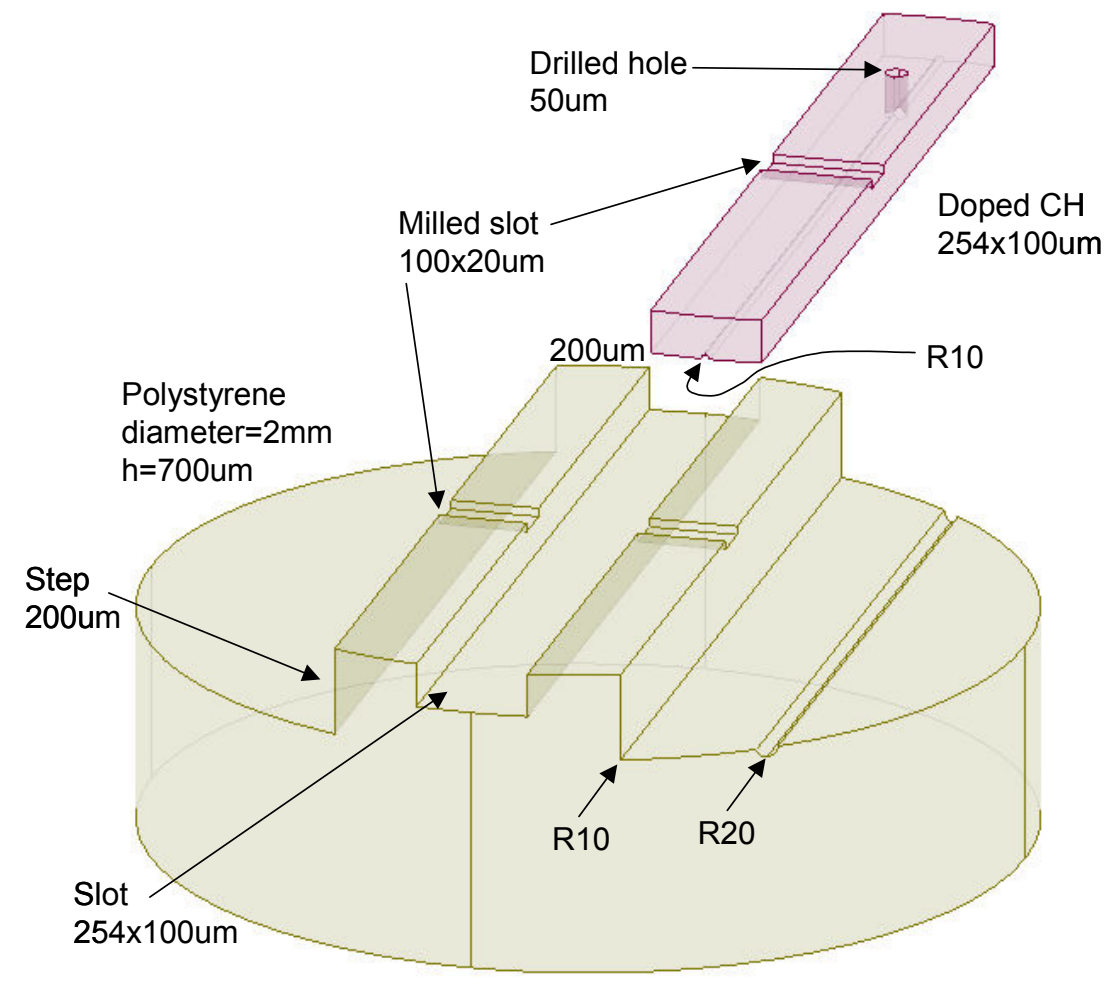

Figure 1. Cylindrical artifact

The assembled artifact will contain many features that could be measured using various NDE methods. Some of these features are listed below.

- Diameter

- Maximum height

- Step height

- Dimensions of upper step

- Radius at the union of the bottom of step and the vertical wall

- Sizes of the grooves 
- Distance from step to groove

- Slot width

- Slot height

- Location of the groove beneath the tracer

- Diameter and location of drilled hole in tracer

- Size and location of slot in tracer

The spherical reference artifact is illustrated in Figure 2. This artifact is intended to replicate a double shell target, which consists of concentric polymer spheres separated by aerogel. The artifact consists of an upper hemispherical shell composed of $1 \% \mathrm{BrCH}$, which mates via a step joint with a hemispherical component made of polystyrene. This lower component contains a replica of an inner capsule from a double shell target. The "inner capsule" and the bottom portion of the artifact are fabricated as a single piece to ensure dimensional stability. The area between the upper and lower components is filled by a machined piece of CRF aerogel that contains several intentional defects. Each of the components of this artifact can be fabricated on a diamond turning machine.

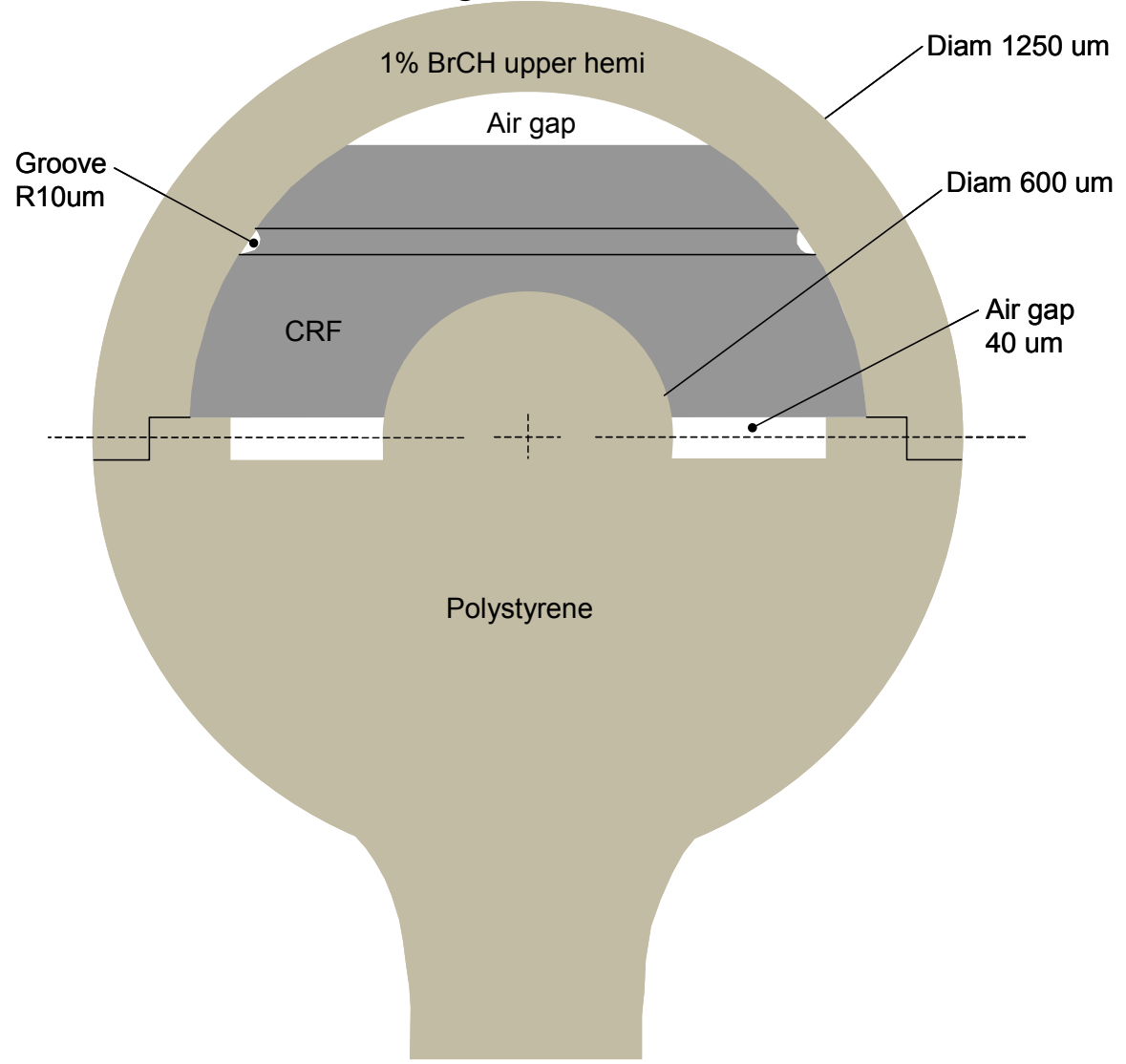

Figure 2. Spherical artifact

The assembled artifact will contain several features that could be measured using various NDE methods. Some of these features are listed below.

- Outer and inner diameters of the upper hemispherical shell

- Diameter of the inner sphere

- Concentricity of outer and inner spheres

- Step joint characteristics 
- Total width of step in the lower polystyrene component

- Size of air gap at the top of the CRF

- Size of air gap below the CRF

- Size and location of groove in the CRF 